DOI: $10.46352 / 23036974.2021 .264$

M. Hakan Yavuz, Nostalgia for

the Empire: The Politics of Neo-

Ottomanism. Oxford University

Press, 2020, 337 pages.*

One can learn a lot about a book by reading its preface and taking into account the author's explanation of the motives and rationale for writing it. In this particular instance, on the first several pages of his most recent work, M. Hakan Yavuz describes the effect that the bloody breakdown of the Yugoslav Federation in the 1990s had on him, but also the impression that those events left on many other likeminded Turks. It is not difficult to understand why the systemic genocide of Muslims in Bosnia and Herzegovina represented a seminal moment in the way that Turks both in the Republic of Turkey and elsewhere around the Globe defined or expressed their identity. In a carefully planned process of dehumanization by Serb intellectual elites and a strategically orchestrated military attack by the Yugoslav People's Army and the Army of Republika Srpska, the Slavophone and predominantly secular Bosnian Muslims, whose ancestors had converted to Islam hundreds of years ago, were labelled and targeted as Turks while their Ottoman Islamic heritage was subjected to total obliteration. Anything and everything that could be associated with the Ottoman Empire's centuries-long rule over the Balkans was supposed to be destroyed in one final and brutal act of de-Ottomanization at the end of the twentieth century. Unsurprisingly, many Turks at the time began identifying with the plight of the Bosnian Muslims and their Ottoman traditions, seeing those attacks and

A somewhat shortened and revised version of this review initially appeared in the journal Middle East Critique, vol. 30, no. 2 (Summer 2021). negative sentiments as being directed against Turks in general. The feeling was exacerbated by the overall indifference of European leaders who failed to respond or react to the mass killings and the horrible atrocities that had happened on their doorstep. These events also brought into the fore the question of Turkey's position, role and responsibility in protecting Ottoman heritage outside of Turkey as it had seemed that nobody else had the interest to do so. Therefore, the trauma of Bosnia and its Muslim population performed an extremely significant role in the emergence of scepticism that Turks began to feel in their country's pro-Western orientation and the pronounced role that Ottoman Islamic heritage began to play in the construction of modern Turkish national and political consciousness.

It is precisely due to these reasons that the Muslims of Bosnia and Herzegovina, along with other local Muslim communities of the Balkans, feature prominently in a book about Turkish nostalgia for the Ottoman Empire and the political ideology that has, rightly or wrongly, been termed as neo-Ottomanism. As remnants and visible reminders of the erstwhile Ottoman Turkish presence and power in the region, they occupy an important place in the formation, preservation and development of this nostalgic sentiment which can be understood as yearning and desire for the revival of past glories, and which has come to serve as a cornerstone of modern Turkish national identity.

In an insightful historical and sociological study which was written with clarity and precision, Yavuz acknowledges the importance of this process and attempts to trace the intellectual origins of Turkey's recent overwhelming enthusiasm for its Ottoman history which can presently be recognized 
not only in popular culture, but also in official state policies and the country's international diplomacy. This nostalgia, articulated through a misinformed and selective approach to symbols, ideas and events from the past, portrays the Ottoman period as a "golden age" and functions as a kind of a utopian narrative which underpins the current understanding of Ottomanism and grounds it in conservative Islamic values. Romantic about the past and critical of the present, the nostalgic discourse of neo-Ottomanism is a product of growing and unresolved tensions between the religious and the national, tradition and modernity, conservativism and progression, which has in the post-imperial world of modern Turkey taken on the form of a struggle between the pro-Western secular elites who tend to renounce Ottoman history, and pro-Islamic elites who see it as an important source of inspiration and pride, as well as a model according to which the present should be moulded.

Throughout his book Yavuz argues convincingly that politicized neo-Ottoman nostalgia, despite what it may seem like on the surface, has little to do with history or the past, and is much more connected to contemporary "feelings of exclusion, marginalization, displacement, and especially discontinuity of identity". In fact, he identifies several major developments that can be considered as key for the emergence and evolution of neo-Ottomanist discourse in Turkish foreign policy, of which the EU rejection of Turkey as a full status member and the genocide in Bosnia are acknowledged as crucial factors. Within this discourse nostalgia operates as a tool for political mobilization and integration since it aims to restore, or rather emulate former Ottoman successes by combining traumatic memory and stressful ex- periences with an idealized, airbrushed and decontextualized understanding of the past. Such an approach validates Turkey's recent proactive engagement in exploring new alliances on the basis of Islamic solidarity and justifies the development of closer ties with Muslim countries. Consequently, modern Turkey wholeheartedly embraces the Ottomans and seeks to strategically exploit their erstwhile geopolitical reach by relying on shared history and supposed "historical responsibility" in order to strengthen and reaffirm relationships with areas that used to be under Ottoman rule. In that sense, the Balkan Muslims and the "post-Ottoman space" they inhabit have been seen as prime targets for the expansion of Turkish political influence by virtue of using public diplomacy and "soft-power".

All of these issues are thoroughly discussed in the eighth and last chapter, The Balkan and Arab Responses to Neo- Ottomanism, where Yavuz analyses the political situation in the "post-Ottoman space" but also provides a critical view of modern Turkish foreign policy. He claims, rightly so, that the Balkan Muslims are usually more open to Turkish involvement in the region and more receptive of the described nostalgic views due to the seemingly positive perception of the Ottoman Empire's historical legacy among them. Indeed, this imported revivalist mentality has found fertile ground throughout the Muslim communities of the broader Balkan region, especially in Bosnia and Herzegovina, Sandžak and Kosovo, where the new wave of Ottoman romanticism has been introduced on account of the existing religious and cultural ties that these societies maintain with Turkey. The particular Balkan variant of Ottoman nostalgia manifests itself in various different ways, 
usually mirroring or imitating the same processes that have originated in Turkey, often through restoration of destroyed architectural monuments, promotion or glorification of historical personalities, commemoration of certain important events from the past, etc. While this is not a problem per se, history can and should be present in our everyday lives, it is the accompanying uncritical, overly emotional and overly political approach to it that can be seen as contentious or provocative, especially in culturally diverse societies such as those in the Balkans where Ottoman heritage is differently interpreted by Muslims and Christians respectively. Therefore, Yavuz is also right to point out that the extremely idealized conception and romanticized image of the Ottoman past, which is offered by modern Turkish politicians, can come across as particularly aggressive, divisive and arrogant in the Balkans since it conveniently ignores reality and downplays the way that the Ottomans are perceived by Christians in the region. Another complementary issue is the overall anti-Western attitude that goes along with Turkey's strained relationship with the EU. While this may be fine for Turkey itself, it can ultimately have a negative reflection on the precarious political position of the Balkan Muslims, some of who are secular and oriented towards Europe. As modern Turkish diplomatic discourse disregards these problematic and disruptive aspects of Ottoman nostalgia in the Balkans, Yavuz states that it has become more of "a source of weakness than strength for the Republic of Turkey", claiming that "Turkey has neither the resources nor the diplomatic finesse to pursue an 'imperial' policy in the Balkans or in the Middle East". While some might not agree with these assessments, it is going to be difficult to argue with his conclusion that failure to "confront" and critically engage with the past could eventually place unwanted constraints on Turkish foreign policy and thus provide Turkey with an extremely difficult challenge as it comes to terms with its role on the regional and global political stage.

EMIR O. FILIPOVIĆ

DOI: $10.46352 / 23036974.2021 .266$

\section{Panos Sophoulis, Banditry in the Medieval Balkans, 800-1500, New Approaches to Byzantine History and Culture Palgrave, 2020, 188 str.}

Pojava razbojništva u srednjem vijeku u našoj historiografiji nedovoljno je istražena, pa knjiga "Razbojništvo na Balkanu u srednjem vijeku, 800-1500" (Banditry in the Medieval Balkans, 800-1500) plijeni pažnju svojim naslovom ne samo historičara, već i znatno šire javnosti željne ovakvih, naizgled egzotičnih tema. Autor je grčki historičar Panos Sophoulis, docent za historiju naroda jugoistočne Europe na atinskom univerzitetu. Doktorirao je na Oxfordu, gdje je jedno vrijeme predavao bizantsku i balkansku srednjovjekovnu historiju. Njegova akademska zanimanja pokrivaju širok spektar pitanja na polju srednjovjekovnih studija, što možemo zaključiti uvidom u njegovu bibliografiju. Knjiga koju ovom prilikom predstavljamo, objavljenja je prošle godine u okviru serije "Novi pristupi bizantskoj historiji i kulturi" (New Approaches to Byzantine History and Culture) koja između ostalog posebnu pažnju posvećuje metodološki inovativnim radovima i studijama o do sada neobrađenim temama. Upravo je to razlog zašto je ovakva tema našla svoje mjesto u njihovom izdavačkom planu. 